\title{
EFFECT OF ANTIOXIDANT TREATMENTS ON BEHAVIOR OF "ZIBDA" MANGO FRUITS CV. (Mangifera indica L.) AT POST-HARVEST AND SHELF LIFE DURING COLD STORAGE.
}

Samaan, L.G. ${ }^{1}$; E.F.A. El-Dengawy ${ }^{2}$ and Heba M.El-Fayoumy ${ }^{1}$

${ }_{1}^{1}$ Pomology Department, Faculty of Agriculture, Mansoura University

2 Pomology Dep., Fac., Agric., Damietta branch, Mansoura University

\begin{abstract}
Mango fruits of "Zibda" cv. were harvested at mature green stage from 20 years-old trees grown in a private orchard in two successive seasons of 20082009. The effect of post-harvest antioxidant treatments on changes of physical and chemical characteristics were studied during cold storage at $5 \pm 1^{\circ} \mathrm{C}$ and $80-85 \% \mathrm{RH}$ for 30 days. Pre-storage tested fruits were soaked in vitamin $\mathrm{C}$ solutions at 0.5 and $1.0 \mathrm{gL}^{-1}$ or vitamin $B_{12}$ solutions at 0.5 and $1.0 \mathrm{mgL}^{-1}$ for $12 \mathrm{hr}$. Changes on these characteristics were determined on stored fruits at 5-day-intervals.

Results of changes in the tested physical and chemical parameters almost indicated an obvious gradual decrease on fruit firmness, fruit juice vitamin $C$ and acidity\% along with fresh peel chlorophyll contents as cold storage period advanced. On the other hand, Fruit weight loss $\%$, fruit juice TSS\%, TSS/acid ratio and total sugars along with fresh peel $\beta$-carotene content were gradually increased as cold storage period advanced. The rates of such decrease or increase were differed due to the tested antioxidant treatment, concentration and parameter.

As for changes of chilling injury incidence "Cl", the results revealed that the first observation of "Cl" symptoms was at the $15^{\text {th }}$ day measurement and then an obvious gradual increase on calculated "Cl" index of all the post-harvest treated and stored fruits till the end of cold storage period. Vitamin $C$ treatments with either 0.5 or $1.0 \mathrm{gL}^{-1}$ " $\mathrm{T}_{1}$ " and " $\mathrm{T}_{2}$ " was the best ones to calculate the fewest index values (reduce "Cl" incidence).
\end{abstract}

\section{INTRODUCTION}

Procedures that minimize post-harvest fruit losses which are worldwide and even much higher in most developing countries well be of great value. Many factors contribute in that respect and effects to control them are often very successful in reducing these losses and ensure sufficient fruits in both quality and quantity. It is also important to report herein that 9 to $16 \%$ of the product is lost due to post-harvest problem. Mango (Mangifera indica L.) is one of the most popular fruit in Egypt having a good source of nutrients, particularly vitamin A and C, TSS (total soluble solids) and dietary fiber. It is also medium source of carbohydrate as ripe mango fruit pulp contains $16.95 \%$ carbohydrate (Salunkhe and Desai, 1984; Pal, 1998). There are a considerable number of mango cultivars under cultivation in Egypt which differ in many ways from one another. Their fruits have distinct variation in physio-morphological characteristic features and chemical composition. Mango fruit quality consists of many attributes that are considered the key components that contribute to a high quality fresh mango and in the 
consumer acceptability of mangoes. They include texture, sweetness, acidity, flavor, volatiles, aroma, nutritional value, chemical components, appearance of flesh color and shelf life (Peter et al., 2007). In Egypt, Anonymous (2008) the total area occupied by mango trees reached 204,284 feddans with annually total production of 466,436 tons.

Post-harvest fruit losses are worldwide and even much higher in most developing countries. Reducing these losses is very important to ensure sufficient fruits in both quality and quantity to be available for every inhabitant in mango planet. Approach improved post-harvest practices that result in losses reduction, improved overall fruit quality and fruit safety have been presumed to optimize shelf life stability of fresh mango fruits for world distribution. Antioxidants activity correlated to changes in mango fruit physical and chemical characteristics during cold storage life are based on the main function of antioxidants in protecting cells from oxidative injury by the created free radicals. This function is thought to be a major mechanism of resistance to plant stresses, and this resistance is likely to depend on the competence of the antioxidant system (Knorzer et al., 1999). The relationship between antioxidants activity in fruits of three apple cultivars and their development was indicated by Kondo et al., (2002). In the same line, Solomon et al., (2006) working on six commercial fig varieties differing in fruit color found that color appearance was well correlated with antioxidant activity. A similar relationship between antioxidants activity and the incidence of chilling injury in fruits during storage period was also the aim of certain studies carried out by Cao et al., (2009) with Loquat fruits and Arafat, (2009) on mango fruits. They reported that chilling injury incidence in stored fruits was judged by activity of antioxidant enzymes. The reduction on chilling injury may be due to enhancing of antioxidant enzymes activity.

The protective role of ascorbic acid activity in plants was explained in the studies of Smirnoff, (1996) and Lee and Kader, (2000). More recent, Terdbaramee et al., (2006) studied the effect of ascorbic acid on controlling post-harvest browning in Lychee fruits. They found that fruits post-harvest soaked in ascorbic acid at $1.0 \mathrm{m \mu}$ and storing at $5^{\circ} \mathrm{C}$ and $90-95 \% \mathrm{RH}$ was the best treatment to control browning incidence and caused a decrease on fruit weight loss and ethylene production which in turn extended the shelf life of the treated and stored fruits to 28 days. Arafat, (2009) came to a similar effect on cold stored fruits of mango cultivar "Hindi Be-Sennara" post-harvest soaked in ascorbic acid solution.

In the current study the effect of post-harvest soaking mango fruits of the cultivar "Zibda" in antioxidant solutions of vitamins $C$ and $B_{12}$ at two concentrations each were examined. The main objectives were comparing and assessing their effects on changes in fruit quality and fruit shelf life with regard to the measurement of important three physical and seven chemical characteristics at successive periodicals during cold storage period for 30 days. 


\section{MATERIALS AND METHODS}

\section{Plant materials, sampling and treatments}

Fully mature green mango fruits of the local cultivar "Zibda" (Mangifera indica L.) were studied during the 2008 and 2009 fruiting seasons. They were obtained from a commercial private orchard in EL-sharkia governorate, Egypt. The fruits were apparently uniform in size and free of visible symptoms of infection, plucked directly from almost similar trees and transported to the laboratory. On arrival the fruits were thoroughly cleaned with tap water and soap to remove dirt and latex, reduce fruit temperature. A total of 285 fruits were selected and randomly divided into five lots. One lot was soaked in distilled water to serve as a control " $\mathrm{T}_{\mathrm{c}}$ ", whilst the remaining four lots were subjected to the following treatments:

1. One lot was soaked in vitamin $C$ solution at $0.5 \mathrm{gL}^{-1}$ " $\mathrm{T}_{1}$ " (Vit.C).

2. One lot was soaked in vitamin $C$ solution at $1.0 \mathrm{gL}^{-1}$ " $\mathrm{T}_{2}$ " (Vit.C).

3. One lot was soaked in vitamin $B_{12}$ solution at $0.5 \mathrm{mgL}^{-1}$ " $\mathrm{T}_{3}$ " (Vit. $\left.\mathrm{B}_{12}\right)$.

4. One lot was soaked in vitamin $B_{12}$ solution at $1.0 \mathrm{mgL}^{-1}$ " $\mathrm{T}_{4}$ " (vit. $\mathrm{B}_{12}$ ).

*. The soaking period was $12 \mathrm{hrs}$.

The treated fruits stored at $5 \pm 1^{\circ} \mathrm{C}$ and $80-85 \%$ relative humidity $(\mathrm{RH})$ for 30 days. At harvest time and at 5 -day-intervals of cold storage period fruit samples were taken to measure changes in fruit quality characteristics and storability during the storage period. Three physical characteristics were measured on intact fruits and seven chemical ones were determined in fruit juice and fresh peels.

\section{Fruit physical characteristics measured at harvest time and during storage period Fruit firmness}

Fruit firmness was measured on two opposite sides of each fruit (2 fruits at 3 replicates/treatment) using a hand penetrometer supplemented with probe of $8.0 \mathrm{~mm}$ in diameter. Each fruit was compressed $2 \%$ of its original diameter. Force in Newton $(\mathrm{N})$ was recorded and the results were expressed as multiplies by 100 according to Reyes and Paull, (1995).

\section{Fruit weight loss $\%$}

Change in this characteristic was measured on 5 fruits at 3 replicates/ treatment. The initial weight of each fruit was recorded at harvest time as well as every 5 days of storage period were reweighted. Percentage of weight loss for each fruit was calculated in relation to its original weight. The obtained results were represented for each treatment as the average weight loss $\%$ of the tested fruits per treatment at the successive intervals of 30 days storage.

\section{Chilling injury incidence (Cl)}

The visible symptoms of chilling injury "Cl" were measured on 5 fruits at 3 replicates/treatment by the method adopted by Chaplin et al., (1991). This method is considered the fruit has "Cl" based on fruit surface area affected by pitting and skin discoloration. Chilling injury result was defined as number of injured Fruits/total fruits tested. The "Cl" index was explained with 
five-point hedonic scale based on the percentage of batch surface area according to Gonzalez-Aguilar et al., (2001). The scale used was divided fruits into 5 successive levels of chilling injury severity as follows:

$1=$ no injury ( $\mathrm{NI}) ; 2=$ light injury (LI) $(<5 \%$ of skin area affected); $3=$ moderate injury (MI) $(6-25 \%$ of skin area affected); $4=$ severe injury (SI) $(26-50 \%$ of skin area affected) and $5=$ very severe injury (VSI) $(>50 \%$ of skin area affected)

The chilling injury index was calculated for each treatment by multiplying the number of fruits in each level by their scores and then dividing this sum by total number of fruits assessed. This index was measured every 5 days up to a maximum of 30 days.

Fruit chemical characteristics determined at harvest time and during storage period

Fruit juice vitamin $\mathbf{C}$ content (Ascorbic acid)

Ascorbic acid content (Vitamin C) in fruit juice was determined in three replicates, $2.0 \mathrm{ml}$ each, adopting the procedure described by Ranganna, (1979) which is based on the oxidation of ascorbic acid with 2, 6 dichlorophenolendophenol dye. The obtained results were expressed as $\mathrm{mg} / 100 \mathrm{ml}$ juice and recorded as an average value per treatment at 5-dayperiodicals.

\section{Fruit juice total acidity percentage}

The titratable $\%$ in fruit juice was determined in three replicates/treatment, $2.0 \mathrm{ml}$ each, by titrating the fruit juice, after diluting with distilled water, against $0.1 \mathrm{~N}$ sodium hydroxide $(\mathrm{NaOH})$ in the presence of phenolphthalein as an indicator to the end point (Ranganna, 1979). The obtained results were expressed as an average citric acid\%/treatment at 5day-periodicals.

\section{Fruit juice total soluble solids percentage (TSS \%)}

This chemical characteristic of fruit juice was measured by the use of an abbe hand refractometer (AOAC, 1985) in three replicates per treatment, $2.0 \mathrm{ml}$ each. The obtained results were recorded as an average value per treatment at 5-day-periodicals.

\section{Fruit juice total soluble solids/acid ratio}

This ratio was calculated from the values recorded for fruit juice TSS and total acidity percentages determined.

\section{Fruit juice total soluble sugars percentage}

The total soluble sugars in fruit juice were determined in three replicates per treatment, $2.0 \mathrm{ml}$ each using phenol sulphuric acid method as described by Sadasivam and Manickam (1996). The obtained results were recorded as an average value per treatment at 5-day-periodicals.

\section{Fruit fresh peel pigment contents}

Pigments determined in fruit fresh peels were total chlorophylls and Bcarotene. Peel samples of the stored fruits $(0.5 \mathrm{~g}$ each) were prepared and extracted in $10 \mathrm{ml}$ of $\mathrm{N}, \mathrm{N}$-dimethyl Formamide (DMF) in the dark for at least $48 \mathrm{hr}$. The extracts were centrifuged for $5 \mathrm{~min}$ at $6000 \mathrm{rpm}$ to take supernatant after remove any suspended material. The absorbance in supernatant was read by UV-Vis spectrophotometer at wave length of 664,647 and $442 \mathrm{~nm}$. 
The obtained readings used to calculate total chlorophyll and ß-carotene contents in peels according to the equations designed by Moran, (1982). The obtained results were recorded as an average value per treatment at 5-dayperiodicals.

\section{Statistical analysis}

The experiment in the 2 tested seasons was laid out in randomized complete block design. The obtained data were subjected to analysis of variance (ANOVA) and the treatment means were separated by F-test and the least significant difference (L.S.D) test at the $5 \%$ level using the statistical package USA, release 5, SAS (1996).

\section{RESULTS AND DISCUSSION}

The effectiveness of antioxidant compounds examined in this study could be attributed to the main function of antioxidant system in protecting fruit cells from oxidative injury by created free radicals or to inhibit acceleration of oxidation processes. Several vitamins have strong antioxidant potential, including water soluble ones such as vitamins B and C. These antioxidant vitamins are one of that have been the focus of most attention in plant (Iskikawa et al., 2001 and Aliston et al., 2007). Before discussing specific data for this investigation, it must be noted that all of the data sets here showed considerable similarity between the two tested seasons. Therefore, the obtained data were reviewed as an average of both studied seasons.

\section{Assessment of physical characteristic changes during cold storage}

Results of physical parameters of fruit firmness, weight loss \% and chilling injury incidence are presented in (Table1). Significant variations in all tested physical characteristics were observed among treatments.

\section{Fruit firmness}

There was a decline in the firmness of cold stored fruits as the storage period advanced (Table1). The rates of decline significantly were varied due to the tested antioxidant treatments. At the end of storage period, the measured fruit firmness was the highest $\left(11.16 \mathrm{~N} / \mathrm{cm}^{2}\right)$ in mango fruits postharvest soaked in vitamin $C$ solution at $0.5 \mathrm{gL}^{-1}$ "T1", followed by those of the same method using vitamin $C$ solution at $1.0 \mathrm{gL}^{-1}$ "T2" $\left(9.96 \mathrm{~N} / \mathrm{cm}^{2}\right)$. The next effect in that respect was to the treatment of vitamin $\mathrm{B}_{12}$ solution at $0.5 \mathrm{mgL}^{-1}$ "T3" with the average value $8.06 \mathrm{~N} / \mathrm{cm}^{2}$, whereas the method of soaking in vitamin $\mathrm{B}_{12}$ solution at $1.0 \mathrm{mgL}^{-1}$ "T4" measured the fewest average value $7.66 \mathrm{~N} / \mathrm{cm}^{2}$. The later inferior treatment is appeared to have an effect almost similar to that of the control one "Tc" $\left(6.92 \mathrm{~N} / \mathrm{cm}^{2}\right)$.

\section{Weight loss $\%$}

The weight loss $\%$ in mango fruit after 30 days cold storage period was less than $4 \%$ for all the post-harvest treated fruits and stored at $5 \pm 1^{\circ} \mathrm{C}$ and $80-85 \%$ RH (Table 1). 
Samaan, L.G. et al.

1

924 
The periodical measurements during cold storage showed an obvious increase in the weight loss $\%$ as the storage period advanced. The rates of increase during storage period significantly were differed. These differences could be related to differences in the water vapor permeability because of the increase in weight loss is attributed to the physiological loss due to respiration and transpiration of water peel tissues and other biological changes taking place in the stored fruits. In mango fruits, this physiological loss in weight is linked to the fact that transpiration continues after the fruit has been harvested (Peter et al., 2007 and Rathore et al., 2007). Otherwise, at the end of storage period insignificant differences were detected either among the tested antioxidant treatments or between each of them and the control one.

\section{Chilling injury incidence}

The concerned results in Table (1) indicated that the typical chilling injury "Cl" symptoms for all the post-harvest treated and cold stored fruits were observed starting from chilling injury index calculation at day 15 . The minor index values were recorded for fruits soaked in vitamin $B_{12}$ solution at $1.0 \mathrm{mgL}^{-1}$ " $\mathrm{T}_{4}$ " (2.10) or vitamin $\mathrm{C}$ solution at $1.0 \mathrm{gL}^{-1}$ " $\mathrm{T}_{2}$ " (2.18) if compared with 2.34 and 2.28 for " $\mathrm{T}_{1}$ " and " $\mathrm{T}_{3}$ ", respectively. Afterward, the periodical measurements for all the tested antioxidant treatments along with the control one showed an obvious increase in "Cl" index values till the end of storage period. At the end of storage period, "Cl" symptoms became more prominent when cold stored fruits were post-harvest soaked in vitamin $B_{12}$ solution either at $0.5 \mathrm{mgL}^{-1}$ " $\mathrm{T}_{3}$ " (3.35) or $1.0 \mathrm{mgL}^{-1}$ " $\mathrm{T}_{4}$ " (3.01). Stored fruits of vitamin $\mathrm{C}$ treatments " $\mathrm{T}_{1}$ " and " $\mathrm{T}_{2}$ " calculated "Cl" index values (2.97 and 2.88, respectively) significantly lower than that of " $\mathrm{T}_{3}$ " one (3.35). This means that vitamin $\mathrm{C}$ treatments relatively did not experience significant "Cl symptoms during cold storage period for 30 days. It is important to state herein that stored controlled fruits calculated index value (2.80) relatively similar to those of vitamin $C$ fruits and almost lower than those of vitamin $B_{12}$ ones. In addition, the calculated "Cl" index values of all the tested antioxidant treatments were lower than $5 \%$. According to the scale used by GonzalezAguilar et al., (2001) these lower values are located in the level of light "Cl" symptoms. This means that cold storage fruits at $5 \pm 1^{\circ} \mathrm{C}$ and $80-85 \% \mathrm{RH}$ reduced the incidence of "Cl" symptoms and this decreasing effect was maximized by the applied post-harvest antioxidant treatments. These findings greatly agreed with those reported by Tasneem, (2004) with mango fruits cultivar "kent". He found that both growth hormone and antioxidant postharvest treatments succeeded to improve tolerance to cold thereby reducing "Cl" incidence. Therefore, he added that it could be allowed storing mangoes at temperature below $10^{\circ} \mathrm{C}$ which would increase the potential storage life of fruits.

The relationship between antioxidants activity and the incidence of chilling injury in fruits during storage period was also the aim of certain studies carried out by Cao et al., (2009) with Loquat fruits and Arafat, (2009) on mango fruits. They reported that chilling injury incidence in stored fruits was judged by activity of antioxidant enzymes. The reduction on chilling injury may be due to enhancing in antioxidant enzymes activity. In the same line, 
Zhao et al., (2009) working on mango fruits at different ripening stages stored at $2^{\circ} \mathrm{C}$ for 12 days. The measurements of " $\mathrm{Cl}$ " index indicated stronger resistance of pre-yellow and yellow fruits to "Cl" compared with green ones. They attributed that to the higher antioxidant capacity involved in the tolerance to chilling temperature. The incidence of "Cl" may be strongly alleviating in the fruit when skin color in beginning changes to yellow from green.

The beneficial effect of antioxidant vitamins $C$ and $B_{12}$ in alleviation of "Cl" in "Zibda" mango fruits during cold storage at sub-optimal temperature was clearly demonstrated during the current study. The positive results on alleviation of "Cl" in stored fruits could be for two reasons, high humidity inside the cold storage room and alleviation of "Cl" due to antioxidant effects. Both the reasons have been well documented in the literature to alleviate the "Cl" disorder in tropical fruits (Meir et al., 1996; Singh and Sudhaker, 2005). The alleviation of "Cl" symptoms in "Zibda" mango fruit due to vitamin C treatment could possibly be through its inhibition effect on oxidation processes acceleration associated with "Cl" (Meir et al., 1996).

\section{Assessment of chemical characteristic changes during cold storage}

Seven chemical parameters were tested in this part of the current investigation. Five of them were determined in stored fruit juice and the rest two in fresh fruit peels at 5-day-periodicals during cold storage period for 30 days. It was cleared an obvious gradual increase in juice TSS\%, TSS/acid ratio and total sugars $\%$ as well as $\beta$-carotene content in fresh peels of the cold stored fruits as the storage period advanced (Tables $2 \& 3$ ).

The increase in TSS\%, TSS/acid and total sugars (Table 2) might be due to the alteration in cell wall structure and breakdown of complex carbohydrates into simple sugars. This increase is directly correlated with hydrolytic changes in starch and conversion of starch to sugar being an important index of ripening process in mango and other climacteric fruits. The role of ascorbic acid as an essential antioxidant is to protect enzymes. Furthermore, it is a cofactor for many enzymes including those involved in this conversion (Kays, 1991; Kittur et al., 2001 and Iskikawa et al., 2001).

On the other hand, results of the same fruit juice as presented in Tables (1, 2 \& 3) indicated a gradual decrease in juice vitamin $C$ and acidity\% along with chlorophylls content in fresh peels at the same storage period. The rates of such increase and decrease were differed due to the tested antioxidant, its concentration and the determined characteristic. These attributions were previously explained by Kondo et al., (2002) who worked on three apples cultivars to associate between antioxidants activity and fruit development. In case of fruit juice vitamin $\mathrm{C}$, the obtained results pointed to an increase in juice of the controlled fruits during the storage period from 10 to 25 days reached the peak at $15^{\text {th }}$ day determination $(82.22 \mathrm{mg} / 100 \mathrm{ml}$ juice $)$. A similar increase was also observed in fruit juice of post-harvest " $\mathrm{T}_{2}$ " treatment at $20^{\text {th }}$ day periodical determination $(67.85 \mathrm{mg} / 100 \mathrm{ml}$ juice). 
J. Plant Production, Mansoura Univ., Vol. 2 (7), July, 2011

2 
The increase in ascorbic acid during these periods of cold storage may be due to the fact reported by Lim et al., (2006) with stored ripe and unripe guava fruits. They indicated that after harvest ascorbic acid is still being synthesized in the living fruit tissues. It is also known that it continued at fruit ripening after harvest and this process leads to significant changes in the contents of the antioxidants. Otherwise, the decreasing trend of juice acidity\% might be due to the degradation of citric acid during ripening or their conversion into sugars and further utilization in metabolic process in the fruit (Rathore et al., 2007).

At the end of cold storage period, among antioxidant treatments studied those of vitamin $\mathrm{B}_{12}$ solution at either 0.5 or $1.0 \mathrm{mgL}^{-1}$ " $\mathrm{T}_{3} \& \mathrm{~T}_{4}$ " were the best to determine the highest increase in juice TSS\% (11.80 and $11.29 \%)$ and TSS/acid ratio (14.83 and 13.99 ratio) as well as $\beta$-carotene content in fresh peels (136.63 and $118.45 \mu \mathrm{g} / \mathrm{g}$ fresh peels) of stored fruits. These super treatments also succeeded to minimize fruit juice acidity\% (0.63\%).

Results in Tables (1\&2) also proved that both vitamins $C$ and $B_{12}$ solutions at higher concentration $\left(1.0 \mathrm{gL}^{-1}\right.$ and $1.0 \mathrm{mgL}^{-1}$, respectively) were the best antioxidant treatments to minimize the reduction of vitamin C (56.19 and $53.68 \mathrm{mg} / 100 \mathrm{ml}$ juice) and to maximize total sugars\% (12.19 and $12.48 \%$ ) in juice of stored fruits at the end of storage period. As for chlorophyll contents, the concerned results in Table (3) indicated that postharvest soaking fruits in solutions of vitamin $B_{12}$ at $0.5 \mathrm{mgL}^{-1}$ " $\mathrm{T}_{3}$ ", vitamin $\mathrm{C}$ at $1.0 \mathrm{gL}^{-1}$ " $\mathrm{T}_{2}$ " or vitamin $\mathrm{B}_{12}$ at $1.0 \mathrm{mgL}^{-1}$ " $\mathrm{T}_{4}$ " were succeeded to reduce the decrease in fresh peel chlorophylls at the end of storage period (216.06, 205.49 and $202.65 \mu \mathrm{g} / \mathrm{g}$ fresh peels, respectively) if compared with "T1" and

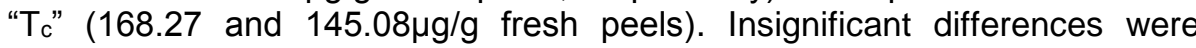
detected among the three former super treatments and each of them was significantly differed with the later two inferior treatments.

It is a point of interest to report herein that among stored fruits of the tested post-harvest treatments, the controlled ones significantly determined the highest decrease in juice acidity $\%(0.63 \%)$ and the highest increase in fresh peel $\beta$-carotene content $(140.99 \mu \mathrm{g} / \mathrm{g}$ fresh peels) at the end of cold storage period. These results in one side greatly confirmed that the storage conditions under study had a positive effect on the behavior of these chemical characteristics of "Zibda" mango fruits during storage period. On the other side, antioxidant vitamins examined could be contradicted with the action of such storage conditions in that respect.

The main function of antioxidant vitamin $C$ in changes of mango fruits quality during storage is to protect fruit cells from oxidative injury by created free radicals which is thought to be depend on the competence of antioxidant enzymes (Knorzer et al., 1999). In addition, Smirnof, (1996); Lee and Kader, (2000) focused the role of ascorbic acid as a protective factor against reactive oxygen species that are formed from photosynthetic and respiratory processes. It is also could be acted as a co-factor for many enzymes. 
J. Plant Production, Mansoura Univ., Vol. 2 (7), July, 2011

3

929 
The effectiveness of antioxidant vitamin $B_{12}$ as evidenced recently is resulted from its importance for characterization of a methionine-synthase enzyme which is required for a large number of biological substances including the de novo of biosynthesis of amino acid methionine and regeneration of methyl group. Methionine is the only sulfur containing amino acid that supports additional roles than simply serving as a building block for protein synthesis. It is a major in transmethylation reactions and intermediate in the biosynthesis of polyamines and phytohormone ethylene. Also, via an as yet fully understood link with plant growth hormones such as cytokinins and auxin (ELchel et al., 1995 and Ravanel et al, 1998). It is a point of interest to put in your knowledge, the use of vitamin $B_{12}$ in the current study is considered the first report of functioning identification of this vitamin in postharvest changes of fruit characteristics during the marketing process with irregular storage conditions and period between harvest and consumption times.

The above post-harvest management through the applied two antioxidant treatments and cold storage at $5 \pm 1^{\circ} \mathrm{C}$ and $80-85 \% \mathrm{RH}$ to extend shelf life of one commercially mango cultivar "Zibda" without adversely affecting their quality at consumption would be of important value to its industry and marketability. Likewise, this post-harvest technology could be applied on other commercially mango cultivars as well as on other fruit crops.

\section{REFERENCES}

Aliston, G. S.; Craft, M. T.; Moulin, M. and Webb, E. M. (2007). Plant needs their vitamins too. Current Opinion in Plant Biology, 10: 266-275.

Anonymous (2008). The cultivated area of mango in Egypt. Statistical report, Ministry of Agriculture, Egypt.

AOAC (1985). Official methods of analysis of association of official agriculture chemists. $14^{\text {th }}$ ed. Washington D C, USA, pp.832.

Arafat, L. A. (2009). Ascorbic acid and tissue browning in mango cv. Hindi Be-Sennara fruits (Mangifera indica L.) under cold storage. J. Agric. Sci. Mansoura Univ., 34(12): 11301-11310.

Cao, S. F.; Zheng, Y. H.; Wang, K.; Jin, P. and Rui, H. (2009). Methyl jasmonate reduces chilling injury and enhances antioxidant enzyme activity in post-harvest loquat fruit. Food Chem., 115:1458-1463.

Chaplin, G. R.; Cole, S. R.; Landrin, M.; Nuevo, P. A.; Lam, P. F. and Graham, G. (1991). Chilling injury and storage of mango (Mangifera indica L.) held under low temperatures. Acta Horticulture, 291: 461471.

Elchel, J.; Gonzalez, J. C.; Hotze, M.; Matthews, R. G. and Schroder, J. (1995). Vitamin-B $B_{12}$-independent methionine synthase from a higher plant (Catharanthus roseus) Molecular characterization, regulation, heterologous expression, and enzyme properties. Eur. J. Biochem., 23:1053-1058. 
Gonzalez-Aguilar, G. A.; Buta, J. G. and Wang, C .Y. (2001). Methyl jasmonate reduces chilling injury symptoms and enhances colour development of "Kent" mangoes. J. Sci .Food Agric., 81:1244-1249.

Iskikawa, A. ;Okamato ,H .;Iwasaki, Y.and Asahi ,Y.(2001).A deficiency of coproporphyoidogen III oxides causes lesion formal ion in Arabidopsis. Plant J., 27(2):89-99.

Kays, S. J. (1991). Post-harvest physiology of perishable plant products. Vas Nostrand Rein Hold Book, AVI Publishing Co, pp: 149-316.

Kitture, F. S.; Saroja, N.; Habibunnisa and Tharanathan, R. N. (2001). Polyccharide-based composite coating formulations for shelf-life extension of fresh banana and mango. Eur. Food Res. Tec., 213: 306311.

Knorzer, O. C.; Lederer, B.; Durner, J. and Boger, P. (1999). Antioxidative defense activation in soybean cells. Physiol. Plantarum , 107: 294302.

Kondo, S.; Tsuda, K.;Muto, N. and Ueda, J. (2002). Antioxidative activity of apple skin or flesh extracts associated with fruit development on selected apple cultivars. Scientia Hort., 96: 177-185.

Lee, S. K. and Kader, A. A. (2000). Pre-harvest and post-harvest factor, influencing vitamin $\mathrm{C}$ content of horticultural crops. Post-harvest Biology and Technology, 20: 207-220.

Lim, Y. Y.; Lim, T. T. and Tee, J. J. (2006). Antioxidant properties of Guava Fruit: comparison with some local fruits. Sunway Academic Journal. 3: 9-20.

Meir, S. ;Philosoph-Hadas, S.; Lurie, S.; Droby, S.; Akerman, M.; Zauberman,G.; Shapiro, B.; Cohen, E. and Fuchs, Y.(1996). Reduction of chilling injury in stored avocado, grapefruit, and bell pepper by methyl jasmonate. Can. J. Bot., 74:870-874.

Moran, R. (1982). Formulae for determination of chlorophyllous pigments extracted with N, N-Dimethylformamide. Plant Physiol., 69: 1376-1381.

Pal, R.K.(1998).Ripening and rheological properties of mango as influenced by ethrel and calcium carbide. J. Food Sci. Tec. Mysore, 35:358-360.

Peter,M.;Leonard, F.;Bernard,C.;Joyce,K.;Victor,G.and Kaswija,M.(2007). Physical and chemical characteristics of off vine ripened mango (Mangifera indica L.)fruit(Dodo). African Journal of Biotechnology, 6 (21):2477-2483.

Ranganna, S. (1979). Manual of analysis of fruit and vegetable products. $2^{\text {nd }}$ Ed. Tata Mcgraw. Hill, publishing company Limited, New Delhi, pp.634.

Rathore, H. A.; Masud, T.; Sammi, S. and Soomro, H. A. (2007). Effect of storage on physico-chemical composition and sensory properties of mango (Mangifera indica L.) variety Dosehari. Pakistan Journal of Nutrition , 6(2): 143-148.

Ravanel, S.; Gakiere, B.; Job, D. and Douce, R. (1998). The specific features of methionine biosynthesis and metabolism in plants. Proc. Nath. Acad.Sci., 95: 7805-7812 USA. 
Reyes, M. U. and Paull, R. E. (1995). Effect of storage temperature and ethylene treatment on guava (Psidium guajava L.) fruit ripening. Postharvest Biol. and Technol., 6: 357-365.

Sadasivam, S. and Manickam, A. (1996). Biochemical methods. Second edition, new age international. India.

Salunkhe,D.K.and Desai,B.B.(1984).Post-harvest biotechnology of fruit.CRC press, Inc. Boca Raton, Florida, 1:77-94.

SAS (1996). Users Guide: Statistics, version 5 Ed. SAS Institute, Inc. Cary, NC, USA.

Singh, S. P. and Sudhaker,D .V.(2005).Effect of modified atmosphere packaging (MAP) on the alleviation of chilling injury and dietary antioxidants levels in "Solo" papaya during low temperature storage. Eur .J.Horti.Sci. , 70:246-252.

Smirnoff, N. (1996). The function and metabolism of ascorbic acid in plants. Ann. Bot.,78:661 -669.

Solomon, A.; Golubowicz, S.; Yablowicz, Z.; Grossman, S.; Bergma, M.; Gottlieb, H. E.; Altman, A.; Kerem, Z. and Flaishman, M. A. (2006). Antioxidant activities and anthocyanin content of fresh fruits of common fig (Ficus carica L.). J. Agric. Food Chem., 54:7717-7723.

Tasneem, A. (2004). Post-harvest treatments to reduce chilling injury symptoms in stored mangoes. M.Sc. Thesis, Macdonald campus of University, Canada.

Terdbaramee, U.; Ratana khanokchai, K.; Kanlavanarat, S. (2006). Control of post-harvest browning of lychee fruit using ascorbic acid. Acta Horticulturea, 712:687-692.

Zhao, Z.; Cao, J.; Jiang, W.; Gu, Y. and Zhao, Y. (2009). Maturity-related chilling tolerance in mango fruit and the antioxidant capacity involved. Journal of the Science of Food and Agriculture, 89(2): 304-309. 
تأثير معاملات مضادات الأكسدة على سلوك ثمار المانجو صنف "زبلة"بعد الجمع و أنثاء التخزين البارد

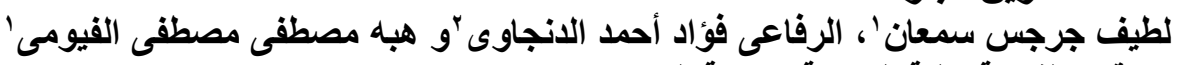

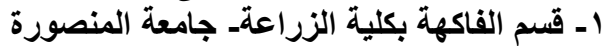

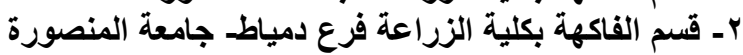

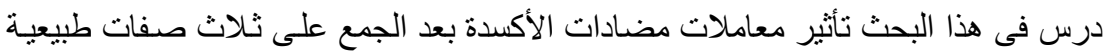

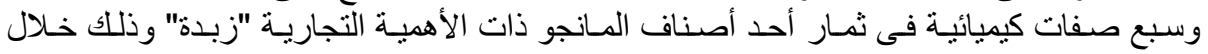

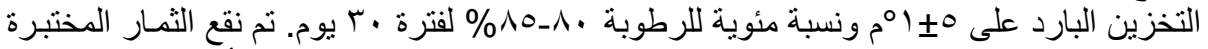

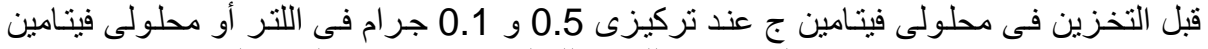

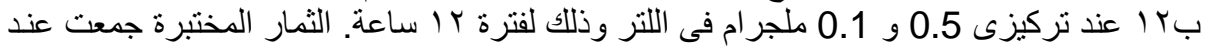

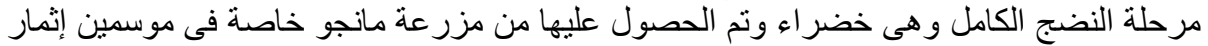

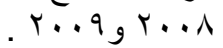

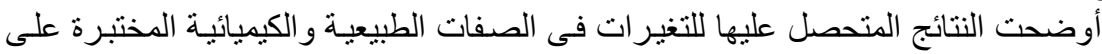

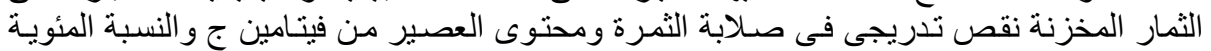

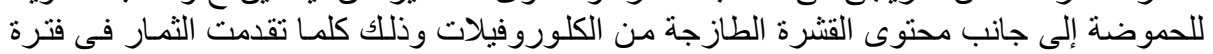

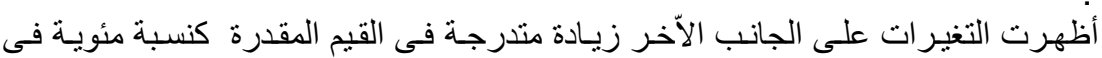

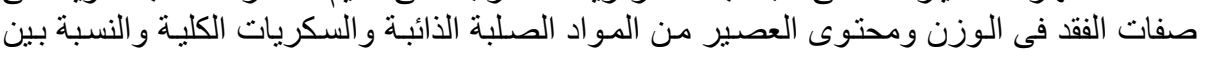

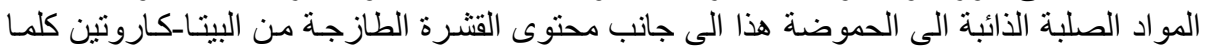

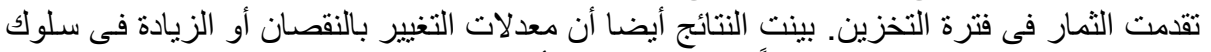
هذه الصفات المختبرة قد إختلفت تبعاً لمحلول مضاد الأكسدة المستخدم وتركيزه وكنلك الصفان الصفة تحت

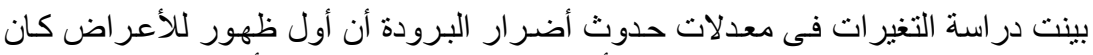

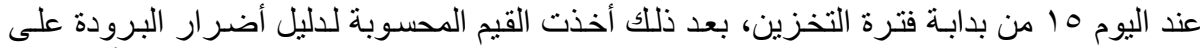

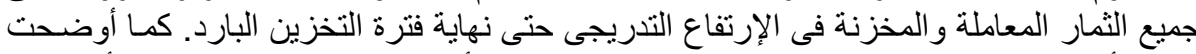

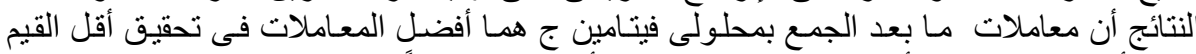

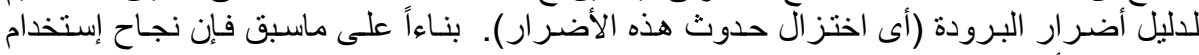

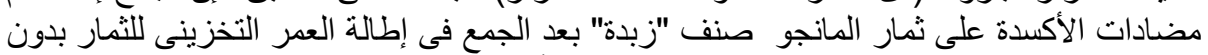

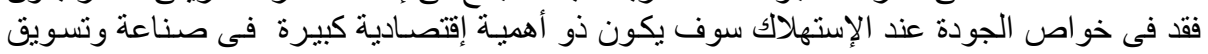

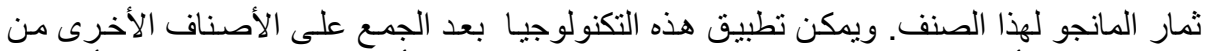

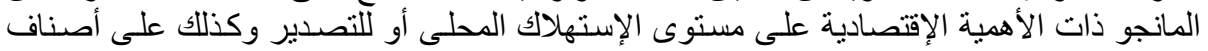

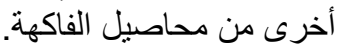

كلية الزراعة - جامعة المنصورة كلية زراعة مشتهر - جامعة بنه
قام بتحكيم البحث

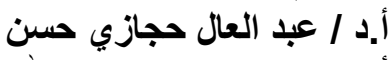

أ.د / أد / عصام عزوز حسب الله حلن 

Table (1): Effect of antioxidant treatments on post-harvest changes in four characteristics of mango fruits cv. "Zibda" at 5-day-intervals during storage at $5 \pm 1^{\circ} \mathrm{C}$ and $80-85 \% \mathrm{RH}$ for 30 days.

\begin{tabular}{|c|c|c|c|c|c|c|c|c|c|c|c|c|c|c|c|}
\hline \multirow{2}{*}{ Treatments } & \multirow{2}{*}{ Symbol } & \multicolumn{7}{|c|}{$\begin{array}{c}\text { Fruit firmness }\left(\mathrm{N} / \mathrm{cm}^{2}\right) \text { during storage in } \\
\text { days }\end{array}$} & \multirow[b]{2}{*}{$\mid \begin{array}{c}\text { Fruit weight } \\
(\mathbf{g})^{\#}\end{array}$} & \multicolumn{6}{|c|}{$\begin{array}{l}\text { Fruit weight loss percentage } \\
\text { during storage in days }\end{array}$} \\
\hline & & $0^{\#}$ & 5 & 10 & 15 & 20 & 25 & 30 & & 5 & 10 & 15 & 20 & 25 & 30 \\
\hline Soaking in water(control) & $\mathbf{T}_{\mathrm{c}}$ & $18.05^{\prime \prime}$ & 16.08 & 14.51 & 13.43 & 12.88 & 7.49 & 6.91 & $322.33^{\prime \prime}$ & 0.35 & 0.98 & 1.80 & 2.26 & 3.03 & .52 \\
\hline Soaking in VitC $0.5 \mathrm{gL}^{-1}$ & $T_{1}$ & 20.50 & 19.19 & 18.54 & 18.23 & 16.77 & 13.07 & 11.16 & 334.57 & 1.30 & 1.94 & 2.72 & 3.23 & 3.17 & 3.63 \\
\hline Soaking in VitC $1.0 \mathrm{gL}^{-1}$ & $T_{2}$ & 19.34 & 18.20 & 17.00 & 15.96 & 14.57 & 12.95 & 9.96 & 301.28 & 0.64 & 1.28 & 1.59 & 2.13 & 2.88 & 3.46 \\
\hline Soaking in Vit ${ }_{B 12} 0.5 \mathrm{mgL}^{-1}$ & $T_{3}$ & 20.23 & 19.21 & 18.54 & 17.94 & 16.02 & 9.74 & 8.06 & 334.39 & 1.10 & 2.26 & 3.00 & 3.42 & 3.65 & 3.80 \\
\hline Soaking in $\mathrm{Vit}_{\mathrm{B} 12} 1.0 \mathrm{mgL}^{-1}$ & $\mathbf{T}_{4}$ & 18.85 & 17.33 & 16.13 & 15.15 & 14.01 & 8.57 & 7.66 & 328.00 & 0.36 & 1.24 & 2.17 & 2.60 & 3.44 & 3.89 \\
\hline$F$ test & & $* *$ & $* *$ & $* *$ & ** & $* *$ & $* *$ & $\star *$ & N.S. & $\star *$ & $\star \star *$ & ** & $\star \star$ & * & N.S. \\
\hline L.S.D & & 1.04 & 1.13 & 1.10 & 1.15 & 1.20 & 1.18 & 1.12 & 34.28 & 0.20 & 0.25 & 0.34 & 0.35 & 0.44 & 0.41 \\
\hline \multirow[t]{2}{*}{ Treatments } & \multirow[t]{2}{*}{ Symbol } & \multicolumn{7}{|c|}{$\begin{array}{l}\text { Chilling injury index of fruits during storage } \\
\text { in days }\end{array}$} & \multicolumn{7}{|c|}{$\begin{array}{l}\text { Vitamin C content ( } \mathrm{mg} / 100 \mathrm{ml} \text { juice) in fruit } \\
\text { juice during storage in days }\end{array}$} \\
\hline & & $0^{\#}$ & 5 & 10 & 15 & 20 & 25 & 30 & $0^{\#}$ & 5 & 10 & 15 & 20 & 25 & 30 \\
\hline Soaking in water(control) & $T_{c}$ & 0.00 & 0.00 & 0.00 & $2.25 "$ & 2.38 & 2.61 & 2.80 & $57.61^{\prime \prime}$ & 55.76 & 74.83 & 82.22 & 64.24 & 63.69 & 54.31 \\
\hline Soaking in VitC $0.5 \mathrm{gL}^{-1}$ & $T_{1}$ & 0.00 & 0.00 & 0.00 & 2.34 & 2.39 & 2.68 & 2.97 & 60.37 & 56.64 & 59.06 & 61.44 & 58.10 & 53.91 & 49.20 \\
\hline Soaking in VitC $1.0 \mathrm{gL}^{-1}$ & $T_{2}$ & 0.00 & 0.00 & 0.00 & 2.18 & 2.29 & 2.61 & 2.88 & 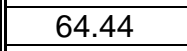 & 53.24 & 62.21 & $64.8 \mathrm{~s}$ & 67.85 & 64.50 & 56.18 \\
\hline Soaking in Vit $_{\mathrm{B} 12} 0.5 \mathrm{mgL}^{-}$ & $T_{3}$ & 0.0 & 0.0 & 0 & 2.28 & 2.43 & 2.80 & 3.35 & 5841 & 45 & 66.60 & 5 & .43 & 5.06 & 34 \\
\hline Soaking in Vit ${ }_{\mathrm{B} 12} 1.0 \mathrm{mgL}^{-1}$ & $T_{4}$ & 0.00 & 0.00 & 0.00 & 2.10 & 2.50 & 2.75 & 3.01 & 61.94 & 59.94 & 67.04 & 68.02 & 60.76 & 60.52 & 53.68 \\
\hline test & & -- & -- & -- & * & N.S. & * & 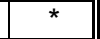 & ** & ** & ** & ** & ** & ** & ** \\
\hline L.S.D 5\% & & -- & -- & -- & 0.15 & 0.14 & 0.12 & 0.35 & 1.03 & 4.40 & 3.95 & 3.43 & 2.74 & 2.77 & 2.88 \\
\hline
\end{tabular}

\#=Determination after soaking period (12h) at $5 \pm 1^{\circ} \mathrm{C}$ directly.

$"=$ These values represent the average of 2008 and 2009 fruiting seasons. 
Table (2): Effect of antioxidant treatments on post-harvest changes in four chemical characteristics of mango fruits cv. "Zibda" at 5-day-intervals during storage at $5 \pm 1^{\circ} \mathrm{C}$ and $80-85 \% \mathrm{RH}$ for 30 days.

\begin{tabular}{|c|c|c|c|c|c|c|c|c|c|c|c|c|c|c|c|}
\hline \multirow[t]{2}{*}{ Treatments } & \multirow[t]{2}{*}{ Symbol } & \multicolumn{7}{|c|}{$\begin{array}{c}\text { Acidity percentage in fruit juice during } \\
\text { storage in days }\end{array}$} & \multicolumn{7}{|c|}{$\begin{array}{l}\text { TSS percentage in fruit juice during storage } \\
\text { in days }\end{array}$} \\
\hline & & $0^{*}$ & 5 & 10 & 15 & 20 & 25 & 30 & $0^{*}$ & 5 & 10 & 15 & 20 & 25 & 30 \\
\hline Soal & $T_{c}$ & $1.73^{\star *}$ & 1.59 & 1.44 & 1.28 & 0.70 & 0.67 & 0.63 & $46^{* *}$ & 5.95 & 0.77 & 11.88 & 12.00 & 1.75 & \\
\hline Soaking in VitC & $T_{1}$ & 1.68 & 1.47 & 1.26 & & 1.05 & & & & 7.95 & & & & & \\
\hline VitC $1.0 \mathrm{gL}^{-1} \quad$ Soa & & 1.60 & 1.56 & & 1.4 & 1.34 & & & & & & & & & \\
\hline Vit $_{B 12} 0.5 \mathrm{mgL}^{-1}$ & & & 1.19 & & 0. & 0.84 & & & & & & & & & \\
\hline Vit $_{\text {B12 }} 1.0 \mathrm{mgL}^{-1}$ Soal & & & & & & 1.10 & & & & & & & & & \\
\hline F t & & & & & & $\star \star$ & & & & & & & & & \\
\hline & & 0.09 & 0.08 & 0.05 & 0.05 & 0.08 & 0.05 & 0.06 & 19 & 0.18 & 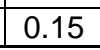 & 0.12 & 0.10 & $0 . \angle 0$ & 0. \\
\hline \multirow[t]{2}{*}{ Treatments } & \multirow[t]{2}{*}{ Symbol } & \multicolumn{7}{|c|}{$\begin{array}{l}\text { TSS/acid ratio in fruit juice during storage } \\
\text { in days }\end{array}$} & \multicolumn{7}{|c|}{$\begin{array}{l}\text { Total sugar percentage in fruits during } \\
\text { storage in days }\end{array}$} \\
\hline & & $\Omega^{*}$ & 5 & & 15 & 20 & & 30 & & 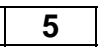 & & & & & \\
\hline So & & 3.1 & & & & .19 & & 17.48 & 9. & 1 & & & & & \\
\hline $\mathrm{Vi}$ & & & & & & & & 7.37 & & & & & & & \\
\hline $\mathrm{L}^{-1} \mathrm{~S}$ & & & & & & & & 10.11 & & & & & & & \\
\hline Soaking in VitB12 & & & 6. & 11.52 & 13.29 & 14.43 & & 14.83 & & & & & & & \\
\hline $1.0 \mathrm{mgL}^{-1}$ So & & 4.7 & 5.56 & 8.17 & 8.91 & 10.27 & 13.31 & 13.99 & 10.64 & 12.17 & 12.29 & 12.38 & 12.48 & 70 & $.4 \varepsilon$ \\
\hline & & $4 t$ & ** & * & $\star \star \star$ & ** & & ** & & & & & & & \\
\hline .S.D 5\% & & 0.33 & 0.40 & 0.40 & 0.59 & 1.29 & 0.78 & 1.05 & 0.05 & 0.04 & 0.08 & 0.06 & 0.26 & 0.05 & 0.05 \\
\hline
\end{tabular}

${ }^{*}=$ Determination after soaking period $(12 \mathrm{~h})$ at $5 \pm 1^{\circ} \mathrm{C}$ directly.

${ }^{* *}=$ These values represent the average of 2008 and 2009 fruiting seasons. 
Table (3): Effect of antioxidant treatments on post-harvest changes in total chlorophyll and $\beta . c a r o t e n e$ content of mango fruits cv. "Zibda" at 5-day-intervals during storage at $5 \pm 1^{\circ} \mathrm{C}$ and $80-85 \% \mathrm{RH}$ for 30 days.

\begin{tabular}{|c|c|c|c|c|c|c|c|c|}
\hline \multirow{2}{*}{ Treatments } & \multirow{2}{*}{ Symbol } & \multicolumn{7}{|c|}{ Total chlorophyll content in fruit peel during storage in days ( $\mu \mathrm{g} / \mathrm{g}$ peels) } \\
\hline & & $\mathbf{0}^{*}$ & 5 & 10 & 15 & 20 & 25 & 30 \\
\hline ing in water (control) & $\mathbf{T}_{\mathbf{c}}$ & $272.56^{\#}$ & 232.59 & 222.31 & 212.62 & 166.86 & 160.21 & 145.08 \\
\hline Soaking in VitC $0.5 \mathrm{gL}^{-1}$ & $T_{1}$ & 322.81 & 277.79 & 265.42 & 249.14 & 192.98 & 184.31 & 168.27 \\
\hline VitC $1.0 \mathrm{gL}^{-1}$ Soaking in & $T_{2}$ & 320.73 & 277.00 & 269.30 & 257.09 & 228.89 & 218.12 & 205.49 \\
\hline Soaking in Vit ${ }_{\mathrm{B} 12} 0.5 \mathrm{mgL}^{-1}$ & $T_{3}$ & 308.17 & 262.47 & 234.21 & 226.43 & 241.70 & 233.60 & 216.06 \\
\hline Vits12 1.0 $\mathrm{mgL}^{-1}$ Soaking in & $\mathbf{T}_{4}$ & 302.74 & 259.09 & 244.46 & 233.67 & 222.52 & 225.00 & 202.65 \\
\hline F test & & ** & ** & ** & ** & ** & ** & ** \\
\hline L.S.D 5\% & & 15.62 & 14.82 & 13.56 & 12.53 & 23.68 & 30.42 & 26.56 \\
\hline \multirow{2}{*}{ Treatments } & \multirow{2}{*}{ Symbol } & \multicolumn{7}{|c|}{ ק.carotene content in fruit peel during storage in days ( $\mu \mathrm{g} / \mathrm{g}$ peels) } \\
\hline & & $0^{*}$ & 5 & 10 & 15 & 20 & 25 & 30 \\
\hline Soaking in water (control) & $T_{c}$ & $76.64^{\#}$ & 88.27 & 98.71 & 107.76 & 122.83 & 129.73 & 140.99 \\
\hline Soaking in VitC $0.5 \mathrm{gL}^{-1}$ & $T_{1}$ & 51.76 & 62.25 & 73.03 & 82.88 & 96.82 & 104.05 & 114.98 \\
\hline Soaking in VitC $1.0 \mathrm{gL}^{-1}$ & $T_{2}$ & 50.51 & 58.87 & 70.82 & 81.63 & 93.43 & 101.83 & 111.59 \\
\hline Soaking in VitB12 $0.5 \mathrm{mgL}^{-1}$ & $T_{3}$ & 76.27 & 83.91 & 96.19 & 107.39 & 118.47 & 127.20 & 136.63 \\
\hline VitB12 1.0mgL-1 Soaking in & $T_{4}$ & 50.10 & 65.73 & 76.68 & 81.22 & 100.29 & 107.69 & 118.45 \\
\hline F test & & ** & ** & ** & ** & ** & ** & ** \\
\hline L.S.D 5\% & & 3.53 & 3.20 & 2.37 & 3.53 & 3.20 & 2.37 & 3.20 \\
\hline
\end{tabular}

${ }^{*}=$ Determination after soaking period $(12 \mathrm{~h})$ at $5 \pm 1^{\circ} \mathrm{C}$ directly.

\#=These values represent the average of 2008 and 2009 fruiting seasons. 